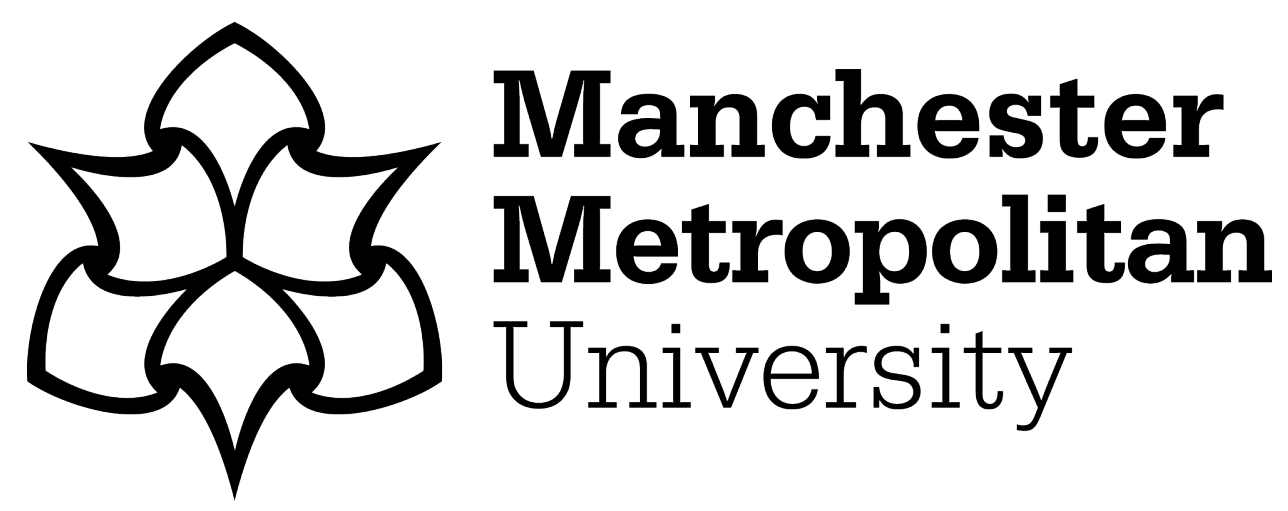

Kilcourse, Carl ORCID logoORCID: https://orcid.org/0000-0001-8475-3154 (2020) Instructing the Heavenly King: Joseph Edkins's Mission to Correct the Theology of Hong Xiuquan. Journal of Ecclesiastical History, 71 (1). pp. 116-134. ISSN 0022-0469

Downloaded from: https://e-space.mmu.ac.uk/622874/

Version: Accepted Version

Publisher: Cambridge University Press (CUP)

DOI: https://doi.org/10.1017/S0022046919001209

Please cite the published version 


\title{
Instructing the Heavenly King: \\ Joseph Edkins's Mission to Correct the Theology of Hong Xiuquan
}

\author{
Carl S. Kilcourse \\ Manchester Metropolitan University \\ Email: C.Kilcourse@mmu.ac.uk
}

\begin{abstract}
This paper examines Joseph Edkins' failed attempt to correct the theology of Hong Xiuquan during his trip to Nanjing in March and April 1861. Through his debates with individual rebels and his written exchange with Hong, Edkins learned that the Taipings were unwilling to accept 'orthodox' teachings and scriptural interpretations that conflicted with their established belief system. Challenging exclusionary and pathologising discourses, the paper shows that Hong's response to Edkins' efforts was rooted not in his 'irrational' modes of thinking, but in his desire to preserve both his revelation-based worldview and the personal authority that it legitimised.
\end{abstract}


After failing the prefectural civil service examination for a third time in 1837, Hong Xiuquan (1814-64) experienced a series of visions that he would later, following his reading of Chinese Christian writings, interpret as a new divine revelation. According to the official account of that revelation, angels descended into the world in 1837 and escorted Hong's soul to heaven. Following his arrival, Hong met the Heavenly Father (Tianfu) and the Heavenly Elder Brother (Tianxiong), Jesus Christ. The Heavenly Father, according to Hong's report, was an anthropomorphic God who had an extremely tall body and wore a high-brimmed hat, a black dragon robe, and a long golden beard. This corporeal deity charged Hong with a mission to expel evil demons from heaven and, following his successful completion of that task, sent him back down to earth to destroy the demons of the world. ${ }^{1}$ Believing that the people of ancient China had known and worshipped God, Hong claimed that his mission was to exterminate the 'demons' (namely, idols, false gods, and the emperor of China) that had usurped the position of God and suppressed the Chinese people's awareness of him for two thousand years. This mission not only provided a religious justification for iconoclasm and rebellion, but also encouraged Hong to present both Jesus and himself as non-divine beings who- - unlike the demonic usurpers - acknowledged the Heavenly Father's status as the 'one true God'.2 The narrative of Hong's ascension and divine mission thus contributed to the development of his radically monotheistic, non-Trinitarian theology. Significantly, the record of Hong's visions also legitimised his authority by presenting him as a son of God and the divinely appointed ruler of China. Hong not only learned during his time in heaven that he was the "natural younger brother' of Jesus (and thus the second son of God), but also received from God the official title of Heavenly King (Tianwang) following the expulsion of the demons from heaven. ${ }^{3}$ Taken together, these revelation-based claims and convictions challenged not only the legitimacy of the emperor, but also the Trinitarian orthodoxy and assumed interpretive authority of foreign Protestant missionaries in China. Despite an early wave of enthusiasm for the Taiping 
iconoclasts, many of the missionaries in China responded to the perceived threat by dismissing the Taipings' theological worldview as a heterodox, and in some cases blasphemous, departure from their 'universal' system of truth. ${ }^{4}$ The discourse of heterodoxy thus promoted the exclusion of the Taipings as theologically abnormal and reinforced the missionaries' image of themselves as the transmitters of 'authentic' Christianity to the Chinese people.

Many writers and historians, from the mid-nineteenth century to the present, have inferred from the record of Hong's visions that he was the victim of a serious mental illness. These interpreters generally cite as diagnostic evidence Theodore Hamberg's (1819-54) account of Hong's falling into a delirium-like state in $1837 .{ }^{5}$ Despite the inadequacy of the evidence and the inaccessibility of Hong's actual state of mind, they have concluded that he suffered from a debilitating mental illness that permanently affected his personality and behaviour as a revolutionary leader. ${ }^{6}$ Lindesay Brine, a British naval officer who served in China during the Taiping Rebellion (1850-64), was one of the earliest interpreters to classify Hong as psychologically abnormal. In his history of the rebellion, Brine not only claimed that Hong's visions were rooted in 'the diseased state of his mind', but also asserted that 'the aberrations of a disordered brain' were responsible for his ideas regarding his unique relation to God. ${ }^{7}$ Almost a century later, the British-trained psychiatrist P. M. Yap gave this interpretation a scientific veneer in his article on Hong's mental health. According to Yap, Hong's recorded visions and behaviour proved that he was 'suffering from delusional ideas of psychotic intensity'. ${ }^{8}$ Although Yap suggested that Hong's illness was most likely 'hysteria', he also claimed that his 'megalomanic convictions' and 'rigidity of mind and character' raised 'some suspicion of a schizophrenic-paranoiac element in his illness'. ${ }^{9}$ This representation of Hong was subsequently embraced by the authors of influential historical works on the Taiping Rebellion. While Vincent Shih described Yap's article as ‘a convincing study of Hung's mental illness', Jen Yu-wen followed his diagnosis in classifying the Taiping leader as 'the victim of 
an acute mental illness of psychotic nature'. ${ }^{10}$ Although recent studies on the Taiping Rebellion have transcended the discourse of Hong's 'madness', its continued influence can be seen in a number of non-specialist works that make reference to the intellectual world of the Taiping leader. ${ }^{11}$ Within such works, Hong has been described as 'the deranged Taiping emperor' and 'a confused and psychotic Chinese Christian' who developed a 'bizarre' apocalyptic vision for the salvation of China. ${ }^{12}$ Most recently, Kathleen Lodwick has labelled Hong as 'mentally unbalanced' and claimed that the disintegration of the Taiping Heavenly Kingdom was caused in part by Hong's growing 'more and more deranged' over time. ${ }^{13}$ Taken together, these various studies present Hong as a psychologically abnormal individual who lost control of both his mind and the revolutionary movement that he created. Like the related discourse of Taiping heterodoxy, this representation has promoted not a critical understanding of Hong's logic and motivations, but rather the exclusion of him and his worldview as deviant and fundamentally irrational.

The purpose of this paper is to problematise the discourse of Hong's 'madness' and to reveal the logic that governed his thinking and behaviour as a religious and revolutionary leader. To uncover that hidden logic, the paper will examine Joseph Edkins' (1823-1905) failed attempt to correct the theology of the Taipings during his trip to Nanjing in March and April 1861. During his two-week stay in the Heavenly Capital (the Taiping designation for Nanjing), Edkins not only preached on the streets and debated theological doctrines with individual Taipings, but also forwarded his papers on the divinity of Jesus and the immateriality of God to Hong Xiuquan. Through those theological debates and his written exchange with Hong, Edkins learned that the Taipings were unwilling to accept 'orthodox' teachings and scriptural interpretations that conflicted with their established, revelation-based worldview. When Edkins tried to demonstrate the incorporeal nature of God, his interlocutors pointed to Hong's ascension to heaven and a scriptural passage that, in their reading, justified his 
anthropomorphic theology. One of those interlocutors similarly responded to Edkins' Christological teachings by suggesting that the biblical text supported Hong's view of Jesus as a non-divine son of God. In his hand-written response to Edkins' paper on the immateriality of God, Hong showed that he, like his apologists, was determined to uphold his established theological worldview. In his alterations to the text and a poem that he appended to the paper, Hong asserted that he had personally seen the image of the Father and emphasised his status as the second son of God and the divinely ordained Heavenly King. Edkins saw in such responses evidence that the Taipings, because of their prolonged social isolation and the 'madness' of their leader, were unreceptive to 'orthodox' instruction and thus inconvertible. Challenging this simplistic and highly exclusive explanation, the analysis of this paper will show that Hong's behaviour was rooted not in his 'irrational' modes of thinking, but in his desire to preserve both his revelation-based worldview and the personal authority that it legitimised. Hong realised that accepting Edkins' doctrines (in particular, the incorporeality of God) would not only invalidate his established theology, but also undermine the legitimising claim that he had seen and been appointed as Heavenly King by an anthropomorphic God. By drawing attention to these religious and political motivations, the paper will show how exclusionary and pathologising discourses have imposed unnecessary limitations on our understanding of Hong's behaviour.

\section{Encouragement from Suzhou: Conversations and Correspondence with Taiping Kings}

The son of a Congregationalist minister, Joseph Edkins was educated at Coward College and the University of London. Following his graduation at the latter institution, he joined the London Missionary Society and departed for China, arriving at Shanghai in $1848 .{ }^{14}$ Edkins engaged in missionary work at Shanghai until March 1858, when he left China and went back 
to England temporarily. He returned to Shanghai with his new wife, Jane Rowbotham Stobbs (1838-61), in September 1859 and moved to Yantai the following year. ${ }^{15}$

Edkins articulated his early ideas on the religious character of the Taipings in a book that was published around the time of his return to China in 1859. Written before his first direct encounters with the Taipings, the book criticised the 'fanatical' beliefs that had turned Hong Xiuquan into a 'fierce warrior' and prevented him from becoming the 'zealous preacher of Christianity' that he might otherwise have been. ${ }^{16}$ Edkins specifically criticised the decision to launch a revolution in the name of God, presenting it as proof that Hong and his followers did not understand the message of the New Testament and the peaceful 'nature' of the Christian religion. ${ }^{17}$ He also suggested that the intimate relationship between Hong's revelation-based orthodoxy and his legitimacy as Heavenly King made him immune to theological instruction and therefore inconvertible. Edkins claimed that there was 'no hope' that Hong would allow foreign missionaries to correct his religious opinions and stressed that he and his followers 'would rather die than give up the objectionable articles of their creed'. ${ }^{18}$ This early representation of Hong as an inconvertible fanatic is inconsistent with Edkins' later effort to instruct and correct the theology of the Taiping leader at Nanjing. This radical shift from pessimism to evangelism was shaped to a large extent by Edkins' positive encounters with the Taipings at Suzhou, whom he and other missionaries visited in July and August 1860. His conversations and correspondence with Taiping leaders (namely, Li Xiucheng [1823-64] and Hong Rengan [1822-64]) at Suzhou convinced him and his colleagues that there was still a possibility that Hong and his followers would convert to 'orthodox' Christianity.

Following their first trip to Suzhou in July 1860, Edkins and Griffith John (1831-1912) received encouraging letters (dated 21 and 22 July 1860) from Hong Rengan and Li Xiucheng. These prominent Taiping kings not only invited their foreign friends to visit them at Suzhou, but also suggested that the missionaries had the capacity to instruct them in Christian truth. 
Hong Rengan, who had joined his cousin (Hong Xiuquan) and the Taipings at Nanjing in 1859, recalled his interactions with Edkins at Shanghai and acknowledged that his 'closed mind' was 'suddenly opened' by Edkins' and other missionaries' teachings on the 'true principles'. ${ }^{19}$ These sentiments were echoed by Li Xiucheng in his letter to Edkins and John. Li not only declared that a letter sent by the missionaries 'explained clearly the true Way', but also gratefully informed them that their 'clear exposition' had opened his 'stopped-up mind' ${ }^{20} \mathrm{~A}$ letter that Edkins wrote in late July 1860 confirms that these communications from Hong and Li reinforced the cautiously optimistic attitude that he had embraced following his first trip to Suzhou. ${ }^{21}$ Whereas Edkins had previously declared that there was 'no hope' of changing Hong Xiuquan's views, he now suggested that the task of correcting the Taipings' belief system was at least theoretically achievable. As Edkins put it,

We are also not unconscious that it is a difficult task which we have undertaken. To persuade the Tai-ping chiefs to resign their pretensions to a special divine revelation among themselves, and personally to their revered head, is what we must aim at. But it is doubtful whether the greatest delicacy and moderation in handling will accomplish this, while an attempt to do so in any spirit of irritating contradiction would certainly fail. $^{22}$

Although Edkins described the task as difficult and the outcome as uncertain, the content of this passage shows that he no longer believed that any attempt to convert the Taipings would inevitably fail. Edkins' first trip to Suzhou and the letters he received from Hong and Li had, in other words, given him hope that it might still be possible to challenge Hong Xiuquan's revelation and introduce a more 'orthodox' form of Christianity among the Taipings.

Edkins and John returned to Suzhou in August 1860 and enjoyed an interview with Hong Rengan. In his published account of the interview, Edkins presented the Taipings as a heterodox but potentially convertible group. Highlighting the Taipings' deviation from Trinitarian theology, Edkins reported that Hong Xiuquan's views on the divinity of Christ were 'imperfect' and that he regarded Jesus simply as 'the greatest of God's messengers' ${ }^{23}$ Although this denial of Jesus' divinity would have alienated many missionaries, Edkins stressed that he 
and his colleagues 'were not told that he [Hong Xiuquan] disbelieved in this truth' and that his 'error' seemed to have stemmed from ignorance, rather than a conscious ('positive') rejection of 'orthodox' truth. ${ }^{24}$ Hong Rengan's replies to other questions suggested, furthermore, that scriptural instruction could provide the remedy for such ignorance. He informed the missionaries that the whole Bible had been published and that it was regarded as having 'supreme authority' by Hong Xiuquan and his followers. ${ }^{25}$ Significantly, he also confirmed that the Taipings would welcome the presence and instruction of missionaries at Nanjing: 'We desire to have missionaries.... Should missionaries come to Nanking chapels will be built for them, and they will be allowed to teach and carry on their work in their own way, and according to their own views. ${ }^{26}$ Hong Rengan, according to John's report, also incentivised the missionaries to join him at Nanjing by claiming that there was a genuine opportunity to convert Hong Xiuquan in the future. He not only presented Hong Xiuquan as 'a pious man' who devoutly worshipped God and constantly read the scriptures, but also communicated his belief that 'much may be done, in course of time, towards putting him right on various points'. ${ }^{27}$ This suggestion that Hong Xiuquan's views could be transformed, together with his reported acceptance of the Bible as 'the inspired Word of God', encouraged Edkins and John to believe that it might still be possible to convert the Taiping leader and establish 'pure and undefiled religion' among his followers. ${ }^{28}$

\section{Imparting 'Orthodoxy': The Divinity of Jesus and the Immateriality of God}

Inspired by his positive and highly encouraging encounters with the Taipings at Suzhou, Edkins decided to make a trip to Nanjing in the early part of 1861 . Although he had already met two prominent Taiping kings (Li Xiucheng and Hong Rengan) during his earlier visits to Suzhou, he hoped that a separate trip to Nanjing would enable him to make contact with the Heavenly King and directly challenge some of the most 'heterodox' beliefs in his theological worldview. 
Despite working diligently to convince Hong and his followers of the divinity of Jesus and the immateriality of God, Edkins discovered at Nanjing that they were unwilling to tolerate challenges to their revelation-based orthodoxy and the system of authority that it legitimised.

Arriving at the Heavenly Capital on 21 March, Edkins recognised that Hong Xiuquan might be less receptive than his cousin (Hong Rengan) to the moral teachings of missionaries. Edkins described the former as a 'fanatical chief' and claimed that he saw himself as a religious teacher, a son of God, and the leader of a divinely ordained crusade to destroy idolatry and 'restore the worship of God among mankind'. Edkins also reported that, because of Hong's unwavering faith in that mission, even the reality of widespread carnage had failed to moderate 'the maniacal sternness of his resolution'. ${ }^{29}$ Despite suggesting that Hong's understanding of his revolutionary mission was fixed and beyond modification, Edkins went into Nanjing hoping 'to bring to the attention of the rebel chief the views held by the Christian Church on the divinity of our Saviour, and of the Holy Spirit'. ${ }^{30}$ This mission statement suggests that Edkins still believed that Hong's principal theological 'errors' (in particular, his denial of Jesus' divinity) were the product of ignorance, rather than a conscious rejection of 'orthodox' truth. As Edkins had previously been told by Hong Rengan that the Heavenly King regarded the Bible as having 'supreme authority', he most probably assumed that the Taiping leader would be willing to explore previously unknown, 'orthodox' doctrines that could be justified with reference to the scriptures. This assumption explains why the missionary arrived at the Heavenly Capital armed with theological papers highlighting the biblical (according to his interpretation) foundations of the 'orthodox' doctrines from which the Taipings had deviated.

During his stay at Nanjing, Edkins met and conversed with the 'heir of Zan', a Taiping official and son of the King of Praise (Zanwang), Meng De'en. Although the young chief 'politely received' Edkins' papers on the divinity of Jesus, he showed during their conversation both his absolute faith in Hong's revelation and his refusal to entertain any doctrines or claims 
that appeared to contradict it. ${ }^{31}$ When Edkins tried to inform him that 'the religion of Jesus came to them from the west', the young chief replied that he had a different view of history that was based on the visions of Hong Xiuquan. ${ }^{32}$ The young chief thus affirmed Hong's revelation and the specific claim that he - not missionaries - had been divinely appointed to restore the worship of God in China. This response showed Edkins that the young chief would not passively accept historical arguments for missionary pre-eminence and would dismiss particular claims that seemed to be at odds with the Taipings' established system of truth. The most powerful demonstration of the latter tendency emerged during his and Edkins' exchange on the nature of God. When the young chief mentioned the command to destroy idols and the offence of using images as objects of worship, Edkins quickly interjected that 'God is without form or image, and it is forbidden to make an image of Him'. On hearing this direct challenge to Hong's anthropomorphic conception of God, the young chief paused and then replied that 'it was wrong to say, absolutely, that God is without form, for the Tien-wang [Tianwang] had certainly seen Him in heaven'. ${ }^{33}$ This short debate was the first time that Edkins observed the Taipings' habit of using Hong's revelation to undercut 'orthodox' theological arguments. Edkins, as shown by his interjection, saw the combination of iconoclasm and anthropomorphism in the Taiping worldview as highly problematic. It was both heterodox and illogical, he believed, to attack physical representations of deities while still believing that God had a material form. However, the young chief's response showed that the Taipings did not recognise that contradiction. The Taipings, in accordance with Hong's account of his ascension to heaven, saw the Heavenly Father as an anthropomorphic deity who wore a high-brimmed hat and a black dragon robe. From their perspective, idols were a problem not because they represented an incorporeal deity in concrete form, but because they had usurped the position of the one supreme God and kept the Chinese people in a state of perpetual ignorance. The young chief's determined defence of this alternative theology told Edkins that the Taipings 
would not passively accept his 'orthodox' teachings. Rather than recognising Edkins' ability to test the veracity of their beliefs, the young chief indicated that he and his superiors would reject all doctrines, arguments, and claims that conflicted with Hong's revelation-based worldview.

Beyond his frustrating conversation with the young chief, Edkins had several discussions and theological debates with a Cantonese rebel named Li. During a meeting on 31 March, Li showed Edkins a letter that had been written for Hong Xiuquan by the American Baptist James Landrum Holmes (1836-61). Although the letter, as a written condemnation of Taiping 'errors', never reached Hong, Edkins explained that it had been read by 'subordinate chiefs' and had prompted $\mathrm{Li}$ to record his own responses to its various questions and criticisms ${ }^{34}$ In reading and discussing those responses, Edkins realised the full extent of Li's commitment to the Taiping worldview. Where the letter asked about the wife of the Heavenly Father, Li replied that God's soul possessed 'eyes, ears, mouth, hands, and ribs' and that his wife may thus have been formed 'as Eve was from Adam'. ${ }^{35}$ Where the letter asked about the meaning of Hong's ascension, Li answered that his soul—not his body—went to heaven and that he informed people of the things he had seen following his return to earth. ${ }^{36}$ As Hong claimed to have seen the Heavenly Father in the form of a man, Edkins tried to discredit his anthropomorphic theology at the source by pointing to the biblical description of God as he 'whom no one has ever seen or can see' (1 Timothy 6:16). Although Hong would later inform Edkins that the 'sacred countenance' could only be seen by certain individuals, Li's response to the missionary's scriptural challenge was to declare that anyone could see the Heavenly Father and that he-like Hong — had personally seen God in a dream. When Edkins drew his attention back to the biblical passage, Li looked closely to establish whether the text referred explicitly to God the Father and then 'remained silent for some time'. ${ }^{37}$ Although Li's hesitation suggested that he was concerned about the theological implications of the passage, 
he circumvented Edkins' interpretive attack by pointing to the text of Genesis 1:27 ('In the image of God he created them') and arguing from it that 'God is like man in body'. Edkins dismissed this interpretation as an example of Li's 'unsafe hermeneutical method' and sought to inform him that the passage referred to 'a likeness in power, in reasoning faculties, and in virtuous dispositions'. Although Li 'readily admitted' this interpretation, he refused, under pressure from Edkins, to add it to his own anthropomorphic explanation in the manuscript. ${ }^{38}$ Li's refusal suggested that he had not genuinely embraced Edkins' figurative reading and would not accept interpretations of scripture that threatened the credibility of Hong's revelation. Li also demonstrated during his and Edkins' debate on the image of God that he was able to use his knowledge of the scriptures to counter Edkins' biblically based criticisms of Taiping theology. In appropriating the weapon of the missionary as an instrument of selfdefence, Li fundamentally challenged the idea that the Taipings' rejection of 'orthodox' Christianity was due to their 'ignorance' of the Bible and their 'unscriptural' faith in Hong's revelation.

Li used his knowledge of the Bible to defend not only the Taipings' anthropomorphic theology, but also their conception of Jesus as a non-divine son of God. Holmes' letter had emphasised the divinity of Christ in asking how the Heavenly King could claim to be the brother of Jesus, a man who was also God (Shen). As Li's response to this question was 'Jesus is man, and not Shen', Edkins grabbed a version of the New Testament that translated God as Shen and highlighted several passages in which the term was applied to Jesus. ${ }^{39}$ Again showing his unwillingness to renounce core Taiping doctrines, Li replied to Edkins' scriptural challenge by stating that 'if Jesus is Shen, he is not Ti [Di]'. Di was the second character from the title Shangdi ('Supreme Lord/God'), which the Gützlaff and Taiping Bibles used as the Chinese name for God. Challenging Li's claim, Edkins picked up a copy of the Taiping New Testament and pointed to the confession of Thomas (John 20:28) and other passages in which Jesus was 
described as $\mathrm{Di}^{40}$ Rather than accepting these passages as evidence of Jesus' divinity, Li maintained his Christological position and argued that biblical statements such as 'The Father and I are one' (John 10:30) did not in fact refer to the nature of Jesus. Whereas Edkins interpreted this passage as a reference to the ontological oneness of the Father and Son, $\mathrm{Li}$, according to Edkins, 'assigned a Socinian sense' in arguing that it meant only 'oneness in object'. After trying to convince him that they were also one in 'power, nature, and authority', Edkins urged Li to accept that 'Christ, in his Divine nature, existed eternally' and was 'the eternal Son of the Father'. ${ }^{41}$ Li's refusal to accept these theological claims is implied by Edkins' statement-following his description of the above exchange-that it was 'highly disappointing' to find individuals such as $\mathrm{Li}$ unashamedly defending views that could only distress 'enlightened' Christians. ${ }^{42}$ Edkins suggested in his report that Li's and other Taipings' attachment to such views was a product of their isolation from 'the influence of common human society' and their being 'beclouded by fanatic errors, based on fancied visions' ${ }^{43}$ Besides underlining the 'abnormality' of the Taipings' theological positions, this explanation deemphasised the fact that Li had shown his willingness and ability to defend Taiping theology through scripture-based arguments. Li not only used a literal interpretation of Genesis 1:27 to defend the Taipings' anthropomorphic theology, but also applied a figurative hermeneutic to John 10:30 to support their conception of Jesus as a non-divine son of God. These interpretations radically challenged the idea that the Taipings might respond to scriptural instruction by accepting their theological 'errors' and converting to 'orthodox' Christianity. Their preferred response, as Li confirmed, was to identify biblical passages and interpretations that could be used to counter theological criticisms and justify the doctrines that Edkins and other missionaries found most repulsive. 


\section{Defending Taiping Theology: Hong Xiuquan's Rejection of 'Orthodox' Christianity}

Edkins' trip to Nanjing enabled him not only to debate theological principles with prominent Taipings, but also to submit papers on Christian doctrine to the Heavenly King Hong Xiuquan. Edkins learned soon after his arrival at Nanjing that Hong had sent letters and edicts to Issachar Jacox Roberts (1802-71) in which he asserted the authority of his new revelation, rejected the 'orthodox' teachings of the missionary, and declared his support for the Arian view of Jesus'

relation to God. ${ }^{44}$ Edkins' reading of those letters and edicts thus told him that Hong would defend his revelation-based worldview and likely reject the package of 'orthodox' truths that he was hoping to deliver to the Taiping leader. Although Edkins persevered and submitted his theological papers to Hong, the response of the Taiping leader showed that he was unwilling to accept any doctrines or claims that conflicted with his established theology and the new revelation on which it was based.

Edkins received a series of communications from Hong Xiuquan during his twelfth day in Nanjing (1 April). The first document was a response to a memorial that had been submitted a few days earlier to request permission for missionaries to reside in Nanjing. Although Hong granted the request, Edkins suggested that the decision was based not on his desire to receive instruction, but on the hope that foreign missionaries would come to the Heavenly Capital and 'recognise him as a prophet divinely commissioned'. ${ }^{45}$ Edkins contextualised this sceptical interpretation by describing the content of an edict that he had received a few days before the arrival of Hong's communications. Despite expressing his fraternal regard for all 'foreign brothers and sisters', Hong urged the missionaries to whom the edict was addressed (namely, Griffith John and those who were present in Nanjing) to recognise him as 'the sun in the heavens, and the sovereign of the world'. ${ }^{46} \mathrm{He}$ also categorically rejected the idea that the Father and Brother (Jesus) existed as equal members of the same Godhead: 
The Father and Brother now descend to rearrange in the world the order of things. On earth and in heaven only the Father is the most honourable. To recognise the Brother without the Father is to lose sight of the distinction of rank. The Father is greater than the Son-the Elder Brother than the younger. ${ }^{47}$

This extract not only shows that Hong rejected the 'orthodox' Christology of the missionaries, but also reveals the Confucian values that shaped his understanding of the relationship between the Heavenly Father and Jesus. Whereas the missionaries saw them as equal, consubstantial members of the triune God, Hong — in accordance with Confucian norms — believed that such ideas obscured the distinction of status that naturally existed between a father and a son. In outlining this reason for rejecting the Christological doctrine of the missionaries, Hong's edict showed that he would defend his theological propositions and not passively accept the 'orthodox' teachings contained in Edkins' papers. Hong further emphasised his unwillingness to accept instruction from missionaries by declaring that God had commanded him to correct scriptural errors and publish a revised version of the Bible. He also explained that he, 'struggling in the Father's behalf', would correct the religious books that the missionaries had presented to him. ${ }^{48}$ Such statements suggested that Hong would respond to Edkins' papers by rejecting his biblical interpretations and all theological claims that conflicted with his revelation-based worldview.

One of the documents that Edkins received on 1 April was a 'memorandum' that Hong had written in response to his reading of submitted papers on Christian doctrine. This memorandum offered a summary of the Taipings' theological worldview and showed Hong's refusal to accept the missionaries' arguments regarding the divinity of Jesus and the incorporeality of God. Affirming Jesus' identity as the saviour of the world, Hong declared that he had sacrificed his life to free people from sin and had saved humankind by 'turning away the Father's wrath'. ${ }^{49}$ Although Hong accepted that Jesus 'ought to be honoured [in the same way] as God', he affirmed neither his ontological union with the Father nor his status as one of 
the three members of the Trinitarian Godhead. Instead, he plainly asserted that there was 'one true God' and claimed that Jesus' salvific intervention was required because people 'had forgotten the Father' (emphasis added) and 'despised that which they should honour'. ${ }^{50}$ Recognising the theological implications of Hong's claims and omissions, Edkins explained that the Taiping leader, despite admitting that Jesus ought to be 'honoured as the Father', avoided 'the use of any language which an Arian would not employ'. ${ }^{51}$ Edkins thus interpreted Hong's memorandum as evidence that the Taiping leader had adopted an Arian Christology and was unwilling to accept Jesus' status as the fully divine son of God. He also learned from the memorandum that Hong was determined to uphold his anthropomorphic conception of God in the face of criticism from missionaries. As Hong explained,

Not having seen God, do not say that He has not been seen. The Elder Brother and I have seen the Father, plainly and certainly so. In the year 1837 I went to heaven, taken there by the Father. He appointed me to slay the dragon and devil, causing me to be supported on angels' wings. ${ }^{52}$

This extract shows that Hong rejected the notion of God's incorporeality to protect his anthropomorphic theology and the new revelation on which his legitimacy and authority rested. If Hong had suddenly accepted the incorporeality of God, he would have contradicted the claim that he had seen the Heavenly Father in the form of a man during his ascension to heaven. Such an admission could have seriously damaged his legitimacy, encouraging his followers to question the reality of his ascension and the specific claim that he had been appointed by God as the Heavenly King. Edkins suggested in his report that Hong's apparent desire to persuade missionaries to recognise him and his claims was evidence that his reason had been affected by a 'monomania'. ${ }^{53}$ Such interpretations, which present Hong as fundamentally irrational, conceal the fact that his assertive behaviour towards missionaries was actually rooted in his recognising their prescribed theology as a threat to his revelation-based worldview and his legitimacy as Heavenly King. 
Hong explained in his memorandum that, because his eyesight was deteriorating, he was unable to correct all the books and papers that the missionaries had presented to him. Hong returned one of Griffith John's papers, complaining that the script was too small. However, Edkins' paper on the divinity of Jesus, which was written in 'a large and plain character', was retained by the Taiping leader. This paper discussed 'proofs' of Jesus' divinity from the Old and New Testaments and provided translations of the Athanasian and Nicene Creeds. ${ }^{54}$ As Edkins believed that Hong's 'anthropomorphism and gross materialism' had prevented him from apprehending the divinity of Jesus, he also submitted for Hong's consideration a paper on the immateriality of God. ${ }^{55}$ The paper affirmed the subordination of matter to spirit and claimed that it was logically necessary for the creator of the world to be ungenerated and formless. It also argued that the Creator, as a formless spirit, could not be perceived. ${ }^{56}$ Rather than embracing these ideas as a foundation for theological enlightenment, Hong corrected the paper in red ink and promptly returned it to the missionary. The title of the paper was That God Has a Visible Form Is Figurative; That God Is without Visible Form Is True (Shangdi youxing wei yu wuxing nai shi lun). Affirming his own revelation and the specific claim that he had seen God in heaven, Hong changed the title of the paper to The Sacred Countenance of Shangdi Only the Son of God Can See. ${ }^{57}$ Where the paper cited John 1:18 ('No one has ever seen God') as evidence of God's incorporeality, Hong commented that the people of the world had not been allowed to see God because of the danger that they would fall into idolatry and make an image of him. ${ }^{58}$ This note suggested that the meaning of the biblical passage was not that God lacked a visible form, but rather that ordinary people, because of their sinful and idolatrous propensities, had been prevented from seeing the image of God. Hong also defended his anthropomorphic theology by inverting Edkins' metaphorical reading of chapter four in the Book of Revelation. Where Edkins argued that the reference to God's sitting on a throne in heaven (Revelation 4:2) was meant to be taken figuratively, Hong struck out the word 
'figurative' $(y u)$ and replaced it with 'real' $($ shi $) .{ }^{59}$ By imposing this literal interpretation, Hong protected the credibility of his visions and the specific claim that he had seen a corporeal deity sitting majestically in heaven. As Edkins believed that Hong's anthropomorphic ideas were the main obstacle to his acceptance of Jesus' divinity, the above comments and corrections told him that the Taiping leader would never embrace the 'orthodox' doctrine of Christ.

Hong, in his comments on Edkins' paper, not only defended his anthropomorphic theology, but also asserted his identity and authority as the divinely appointed Heavenly King. Emphasising his status as the second son of God, Hong erased the word 'only' $(d u)$ where Edkins' paper referred to Jesus as the 'only-begotten son' (dusheng zi) of God. ${ }^{60}$ In a poem that he appended to the paper, Hong clarified that he-like Jesus—was originally 'produced' (sheng) by the Father. Covering the back page of Edkins' paper with its bold red characters, the poem declared,

Shangdi is angered most over the idols;

The image of the Father [Ye xiang] may not be seen by earthly people.

Christ and I were produced by the Father,

And because I was in the Father's bosom, I have seen God.

The Father created Adam in his image-

If you recognize this you may still be pardoned.

Formerly I saw the Father's sacred countenance [Ye shengyan];

The Father and his sons, the elder and younger brothers, are not uncertain.

The Father and the Elder Brother have brought me to sit in the Heavenly Court;

Those who believe truly shall enjoy blessings in ten thousand forms. ${ }^{61}$

The first two lines of the poem reiterate the point that Hong made in his comment on John 1:18: ordinary people were not allowed to see the image of God because of the danger that they would manufacture a religious idol on the basis of what they had seen. The fact that 'earthly people' had not seen the image of God did not, in other words, prove that God was formless. Emphasising his uniqueness in relation to ordinary mortals, Hong claimed that he was a natural son of God whose intimacy with the Father had enabled him to 'see' (jian) the 'sacred countenance' (shengyan). Hong, like Li, also pointed to the biblical description of God's creating humankind in his image (Genesis 1:27) to substantiate the claim that he had seen the 
Heavenly Father in the form of a man. Finally, Hong communicated the political significance of his anthropomorphic theology at the end of the poem. As Hong's legitimacy was founded on his encounter with a corporeal deity, Edkins' paper on the immateriality of God questioned both the reality of his ascension and his claim to be the divinely appointed Heavenly King. In declaring that he had been sent by God and Jesus 'to sit in the Heavenly Court', Hong dismissed this perceived challenge and affirmed both his revelation-based worldview and the personal authority that it legitimised.

Hong's written exchange with Edkins was not the first demonstration of his unwillingness to tolerate perceived challenges to his authority as Heavenly King. Almost five years before Edkins' arrival at Nanjing, Hong ordered the killing of the Eastern King Yang Xiuqing for what he saw as plotting to seize the Taiping throne. Prior to his assassination in 1856, Yang had acted as the mouthpiece of the Heavenly Father, communicating the will of God to Hong and his followers. ${ }^{62}$ Although Yang originally used this charismatic role to confirm Hong's revelation and encourage loyalty among his followers, he later employed the voice of God to criticise Hong's character and conduct as Heavenly King. During one of his recorded communications from 1853, Yang instructed Hong to be more lenient towards female officials and indicated that he should allow his 'younger brothers' to review all cases of capital punishment. ${ }^{63}$ Interpreting these and other later communications as evidence of a plot to usurp his position, Hong launched a pre-emptive attack that resulted in the killing of Yang, his family members, and all known associates of the Eastern King. ${ }^{64}$ This particular episode shows that Hong was keenly aware of the ways in which alternative streams and readings of revelation could be used to undermine his authority as Heavenly King. Although Edkins' trip to Nanjing was not motivated by political ambitions, Hong recognised that his doctrines and biblical interpretations - like the charismatic practices of Yang-had the potential to weaken his established worldview and the personal authority that it legitimised. In his response to Edkins' 
paper, Hong neutralised that perceived threat and emphasised that he, rather than Edkins or any other missionary, had the power to define and interpret the revelations of God.

\section{From Pathology to Legitimacy: Explaining Hong Xiuquan's Response to Instruction}

Armed with the scriptures and his theological papers, Edkins went into Nanjing believing that the task of correcting Hong's 'errors' was at least theoretically achievable. This cautiously optimistic attitude did not, however, endure beyond his two-week stay at Nanjing. Through his conversations with individual rebels and his written exchange with Hong, Edkins learned that the Taipings were unwilling to receive 'orthodox' instruction and rejected all scriptural interpretations that seemed to contradict their revelation-based worldview. He also discovered that the Taipings' reliance on a new revelation encouraged them to present themselves as transmitters of truth and teachers-rather than pupils-of missionaries. When Edkins, for example, pointed to scriptural passages and urged Hong to accept the immateriality of God, Hong corrected his interpretation of the cited passages, affirmed his new revelation, and encouraged the missionary to recognise both the corporeality of God and the legitimacy of his second son. On the basis of this and other experiences at Nanjing, Edkins concluded that 'the design of converting the Taiping chief to correct scriptural opinions was a hopeless one' ${ }^{65}$

In explaining the failure of his mission, Edkins downplayed the contribution of his methods and suggested that the fault lay exclusively with Hong and his followers. Focusing on what he saw as the Taipings' abnormal social development, Edkins argued that one of the main reasons for their resistance to instruction was the early isolation of the God Worshippers and their prolonged disconnection from the missionary community. Before the Taipings had launched a revolution and developed their own 'deviant' interpretations of the Bible, a missionary, Edkins claimed, could have taught them the 'peaceful' nature of Christianity and shown them the 'legitimate' (that is, missionary-approved) way to read the biblical text. ${ }^{66}$ 
Lacking such guidance (or semantic control) from missionaries, the Taipings were allowed to develop their ideas and interpretations independently to the point that 'they were beyond the control of any human adviser' and expected missionaries to acknowledge Hong as a son of God. ${ }^{67}$ Edkins underlined this representation of the Taipings as uncontrollable by suggesting that Hong Xiuquan, as evidenced by his theological claims and his belief in religious visions, had 'lost the proper balance of his mind' ${ }^{68}$ Edkins claimed that Hong possessed a 'monomaniacal predisposition' and that his reading of Christian books in a state of sickness had 'turned his brain'. ${ }^{69}$ He also reported that the Taiping leader, despite being 'thoroughly respectful and friendly' towards foreign Christians, 'in his madness' believed that he had divine authority to deliver new revelations to the world. Edkins argued that Hong, because he was guided by such 'irrational' beliefs, automatically responded to the theological challenges of missionaries by repeating the 'pretensions' that were based on his visions. ${ }^{70}$ This 'psychological' explanation, which was based on highly problematic assumptions about Hong's mental state, not only promoted the exclusion of the Taiping worldview as a product of madness, but also fed Edkins' and other missionaries' belief that acceptance of their 'orthodox' system of truth was the natural and rational response to theological instruction. The explanation thus allowed Edkins to maintain his essentialist notion of Christianity and to suppress the suggestion that his meanings and interpretations might not be universally valid.

The purpose of this paper was to move beyond exclusionary discourses and to establish Hong's actual reasons for rejecting Edkins' theological doctrines and scriptural interpretations. By carefully examining his response to Edkins' teachings, the paper has shown that Hong's behaviour was rooted not in his 'irrational' modes of thinking, but in his desire to preserve both his revelation-based worldview and the personal authority that it legitimised. The Taipings' desire to protect their established belief system was first communicated to Edkins by the young chief ('heir of Zan') and a theologically informed Taiping named Li. When Edkins tried to 
teach these individuals that God was 'without form or image', the young chief confidently asserted that Hong had seen his body and Li pointed to a scriptural passage (Genesis 1:27) that, according to his interpretation, corroborated their anthropomorphic conception of God. Similarly, Li responded to Edkins' teachings on the divinity of Jesus by suggesting that the biblical text supported Hong's view of him as a non-divine son of God. Like his two apologists, Hong communicated his refusal to change his established theology in his response to Edkins' paper on the immateriality of God. Hong not only affirmed, through his alterations to the paper's title, that he had seen the 'sacred countenance' of God, but also commented that the biblical reference to God's sitting on a throne in heaven (Revelation 4:2) was meant to be interpreted literally, rather than figuratively as Edkins had argued. In a poem that he appended to the paper, Hong pointed to Genesis 1:27 as further evidence for his anthropomorphic theology. He also reiterated that he had seen the 'sacred countenance' and declared that he had been sent by God and Jesus 'to sit in the Heavenly Court'. Such claims confirm that Hong's rejection of 'orthodox' doctrines (in particular, the immateriality of God) was prompted by his desire to protect not only his established theology, but also the new revelation on which his worldview and legitimacy were based. In seeking to preserve both his orthodoxy and his authority, Hong showed that he was not too dissimilar to Edkins and other missionaries who uncritically dismissed his behaviour as a product of madness.

\footnotetext{
1 'The Taiping heavenly chronicle' (1862 [written 1848]), in Franz Michael and Chung-li Chang (eds), The Taiping Rebellion: history and documents, vol. 2: documents and comments, parts 1-4, Seattle 1971, 51-76; 534, 57-8, 62. Taiping tianri (Taiping heavenly chronicle; 1862 [written 1848]), 3-4, 10, 16. Cambridge University Library, Wade Collection. FC.171.7(5). F 63.
${ }^{2}$ For discussion of Hong's mission and its impact on his theology, see Carl S. Kilcourse, Taiping theology: the localization of Christianity in China, 1843-64, New York 2016, 49-63, 95-9.

3 'The Taiping heavenly chronicle', 57, 59 (original translation revised). Taiping tianri, 9, 12-13.
} 
${ }^{4}$ See Kilcourse, Taiping theology, 2-4, 82-5.

${ }^{5}$ Theodore Hamberg, The visions of Hung-Siu-tshuen, and origin of the Kwang-si insurrection, Hong Kong 1854, $8-13$.

${ }^{6} \mathrm{P}$. M. Yap acknowledged that the available data relating to Hong's 'illness' could be deemed inadequate 'from the scientific point of view'. P. M. Yap, 'The mental illness of Hung Hsiu-ch'üan, leader of the Taiping Rebellion', The Far Eastern Quarterly 13, no. 3 (May 1954), 287-304; 289.

${ }^{7}$ Lindesay Brine, The Taeping Rebellion in China: a narrative of its rise and progress, based upon original documents and information obtained in China, London 1862, 67, 352.

${ }^{8}$ Yap, 'The mental illness of Hung Hsiu-ch'üan', 296.

${ }^{9}$ Yap, 'The mental illness of Hung Hsiu-ch'üan', 299-300.

${ }^{10}$ Vincent Y. C. Shih, The Taiping ideology: its sources, interpretations, and influences, Seattle 1967, 448. Jen Yu-wen, The Taiping revolutionary movement, New Haven 1973, 17.

${ }^{11}$ One exception is Stephen Platt's monograph, which refers explicitly to Hong's 'madness' in its analysis of the Taiping Rebellion. Stephen R. Platt, Autumn in the Heavenly Kingdom: China, the West, and the epic story of the Taiping Civil War, New York 2012, 115, 338.

${ }^{12}$ W. J. F. Jenner, 'China and freedom', in David Kelly and Anthony Reid (eds), Asian freedoms: the idea of freedom in East and Southeast Asia, Cambridge 1998, 65-92; 86. K. K. Yeo, 'Chinese Christologies: images of Christ and Chinese cultures', in Francesca Aran Murphy (ed.), The Oxford handbook of Christology, Oxford 2015, $393-407 ; 395$.

${ }^{13}$ Kathleen L. Lodwick, How Christianity came to China: a brief history, Minneapolis 2016, 19-20.

${ }^{14}$ S. W. Bushell, 'Obituary notices: Rev. Joseph Edkins, D.D.', The Journal of the Royal Asiatic Society of Great Britain and Ireland 38, no. 1 (Jan. 1906), 269-71; 269. D. MacGillivray (ed.), A century of Protestant missions in China (1807-1907): being the centenary conference historical volume, Shanghai 1907, 661.

${ }^{15}$ Alexander Wylie, Memorials of Protestant missionaries to the Chinese: giving a list of their publications, and obituary notices of the deceased, Shanghai 1867, 187.

${ }^{16}$ Joseph Edkins, The religious condition of the Chinese: with observations on the prospects of Christian conversion amongst that people, London 1859, 269-70.

${ }^{17}$ Edkins, The religious condition of the Chinese, 285-6.

${ }^{18}$ Edkins, The religious condition of the Chinese, 270. 
${ }^{19}$ Hong Rengan, 'Hong Rengan's letter inviting Joseph Edkins to an interview' (21 July 1860), in Franz Michael and Chung-li Chang (eds), The Taiping Rebellion: history and documents, vol. 3: documents and comments, parts 5-6, Seattle 1971, 1,111-14; 1,112.

${ }^{20}$ Li Xiucheng, 'Li Xiucheng's letter to Joseph Edkins and Griffith John inviting them to visit Suzhou' (22 July 1860), in Michael and Chang (eds), The Taiping Rebellion, vol. 3, 1,114-16; 1,115-16.

${ }^{21}$ Edkins first articulated his cautiously optimistic attitude in his and John's account of their first trip to Suzhou. 'Visit of Messrs. Edkins, John, Macgowan, and Hall, to the Chinese insurgents', The Missionary Magazine and Chronicle 24, no. 293 (Oct. 1860), 270-7.

${ }^{22}$ Joseph Edkins, 'Letter of the Rev. Joseph Edkins to the foreign secretary' (30 July 1860), The Missionary Magazine and Chronicle 24, no. 294 (Nov. 1860), 298-9; 299.

${ }^{23}$ Joseph Edkins, 'A report by Rev. Joseph Edkins' (1860) [hereinafter 'Report'], in Prescott Clarke and J. S. Gregory (eds), Western reports on the Taiping: a selection of documents, London 1982, 241-6; 241. Originally published in North China Herald, 11 August 1860.

${ }^{24}$ Edkins, 'Report', 241.

${ }^{25}$ Edkins, 'Report', 243.

${ }^{26}$ Edkins, 'Report', 243.

${ }^{27}$ Griffith John, 'Visit of missionaries to Soo-chow; conferences with Hung-Jin' (16 August 1860), The Missionary Magazine and Chronicle 24, no. 294 (Nov. 1860), 299-302; 302.

${ }^{28}$ John, 'Visit of missionaries to Soo-chow', 302.

${ }^{29}$ Joseph Edkins, 'Narrative of a visit to Nanking' [hereinafter 'Narrative'], in Jane R. Edkins, Chinese scenes and people: with notices of Christian missions and missionary life in a series of letters from various parts of China, London 1863, 241-307; 266.

${ }^{30}$ Edkins, 'Narrative', 266.

${ }^{31}$ Edkins, 'Narrative', 267-8.

${ }^{32}$ Edkins, 'Narrative', 269.

${ }^{33}$ Edkins, 'Narrative', 269.

${ }^{34}$ Edkins, 'Narrative', 287-8.

${ }^{35}$ Edkins, 'Narrative', 288.

${ }^{36}$ Edkins, 'Narrative', 288.

${ }^{37}$ Edkins, 'Narrative', 288-9. 
${ }^{38}$ Edkins, 'Narrative', 290.

${ }^{39}$ Edkins, 'Narrative', 289.

${ }^{40}$ Edkins, 'Narrative', 289.

${ }^{41}$ Edkins, 'Narrative', 290-1.

${ }^{42}$ Edkins, 'Narrative', 291.

${ }^{43}$ Edkins, 'Narrative', 288.

${ }^{44}$ Edkins, 'Narrative', 272-3.

${ }^{45}$ Edkins, 'Narrative', 292.

${ }^{46}$ Edkins, 'Narrative', 292.

${ }^{47}$ Edkins, 'Narrative', 292.

${ }^{48}$ Edkins, 'Narrative', 292.

${ }^{49}$ Edkins, 'Narrative', 294-5.

${ }^{50}$ Edkins, 'Narrative', 294.

${ }^{51}$ Edkins, 'Narrative', 295.

${ }^{52}$ Edkins, 'Narrative', 294.

${ }^{53}$ Edkins, 'Narrative', 293.

${ }^{54}$ Edkins, 'Narrative', 294-5.

${ }^{55}$ Edkins, 'Narrative', 295-6.

56 'The Tianwang's comment on Edkins' essay on God', in Michael and Chang (eds), The Taiping Rebellion, vol.

3, 1,204-5. Joseph Edkins, Shangdi youxing wei yu wuxing nai shi lun (That God has a visible form is figurative; that God is without visible form is true [with Hong Xiuquan's comments and corrections]), 1. British Library, Chinese Collections, Asian and African Studies Department. Or. 8143. Edkins, 'Narrative', 296.

57 'The Tianwang's comment on Edkins' essay on God', 1,204 (original translation revised). Edkins, Shangdi youxing wei yu wuxing nai shi lun, 1. Edkins, 'Narrative', 296.

${ }^{58}$ Edkins, Shangdi youxing wei yu wuxing nai shi lun, 1. Edkins, 'Narrative', 296-7.

${ }^{59}$ Edkins, Shangdi youxing wei yu wuxing nai shi lun, 1. Edkins, 'Narrative', 297.

${ }^{60}$ Edkins, Shangdi youxing wei yu wuxing nai shi lun, 1. Edkins, 'Narrative', 297.

61 'The Tianwang's comment on Edkins' essay on God', 1,205 (original translation revised). Edkins, Shangdi youxing wei yu wuxing nai shi lun, 2.

${ }^{62}$ The Western King Xiao Chaogui similarly acted as the mouthpiece of Jesus prior to his death in 1852. 
63 'Book of declarations of the divine will made during the Heavenly Father's descent to earth [II]' (1853), in Michael and Chang (eds), The Taiping Rebellion, vol. 2, 197-220; 203-6. Tianfu xiafan zhaoshu (Book of declarations made during the Heavenly Father's descent to earth [II]; 1853), 8, 10-12. National Library of Australia (website). Available at http://nla.gov.au/nla.gen-vn2029594 (accessed 21 Oct. 2010).

${ }^{64}$ For discussion of Yang's charismatic practices and the fratricidal chaos of 1856, see Kilcourse, Taiping theology, 143-53.

${ }^{65}$ Edkins, 'Narrative', 299.

${ }^{66}$ Edkins, 'Narrative', 273-4.

${ }^{67}$ Edkins, 'Narrative', 274.

${ }^{68}$ Edkins, 'Narrative', 299.

${ }^{69}$ Edkins, 'Narrative', 293.

${ }^{70}$ Edkins, 'Narrative', 270. 